\section{The Weather of the $1780 \mathrm{~s}$ over Europe \\ JOHN KINGTON}

John Kington's book, the first of its kind, gives a definitive account of the weather of the 1780 s based on a series of historical weather maps, and will be of interest to both historical and climatic researchers.

"This is a lovely piece of old-fashioned scholarship... fully accessible to anyone with an interest in the weather.

New Scientist

\section{Proceedings of the Eighteenth Lunar Planetary Science Conference}

Edited by G. RYDER

This book represents a broad survey of the latest research raking place in a variety of planetary and astronomy related fields. It includes topics such as lunar geology, chemistry and evolution; studies of Venus, Mars and the outer solar system; analysis and origins of meteorites and cosmic dust; comet and asteroid studies; the solar nebula, planetary origins, and planetary differentiation; cosmic rays; remote sensing of planets; and planetary physics. $\begin{array}{llllll}768 p p & 1988 \quad 0 \quad 521 & 35090 & 5 & \mathbf{8} 60.00 & \text { net }\end{array}$

For further information on Cambridge titles in Geology please write to Jacqueline Arthurs at the address below

\section{Now in paperback Thermoluminescence of Solids}

\section{S. W.S. MCKEEVER}

This book presents a unified approach to the topic of thermoluminescence and brings together the previously fragmented specialist approaches to the subject. It stresses the importance of the solid state aspects of the phenomenon and links these to applications in dating, dosimetry and geology.

'... an excellent, critical introduction to the subject...'

Cambridge Solid State Science Series $376 p p .1988 \quad 052136811$ I Pb $\$ 17.50$ net

\section{Drifting Continents and Shifting Theories}

The Modern Revolution in Geology and Scientific Change

\section{H. E. LE GRAND}

This innovative book uses the story of how the global theory of plate tectonics achieved its present shape and focus to introduce the question of the nature of scientific change and its philosophical analysis. The history of the rise to prominence of this theory is interwoven with reflective discussions of its context and the development of science more generally.

$$
\begin{array}{lllllll}
319 \text { Pp. } 1988 & 0 & 521 & 32210 & 3 & \text { Hc } \$ 30.00 & \text { net } \\
& & 0 & 521 & 31105 & 5 & \text { Pb } \$ 10.95 \text { net }
\end{array}
$$

\section{Cambridge University Press}

The Edinburgh Building, Shaftesbury Road, Cambridge CB2 2RU. 


\title{
Geology Today
}

\section{Published under the co-sponsorship of The Geological Society and The Geologists' Association by Blackwell Scientific Publications Ltd}

\section{Editors}

\author{
J.H. McD. Whitaker 11 Guilford Road, Leicester, England \\ Peter J. Smith 32 St James Close, Hanslope, Milton Keynes, England
}

Geology Today is a magazine for both amateur and professional geologists. The only English-language journal of its kind, Geology Today is designed to provide a wide audience of both specialists and non-specialists with intelligible and readable information from different areas of specialization within both pure and applied geology. The editors select two or three feature articles each issue on various topics of current geological interest. Shorter articles, notes, news of geological meetings, exhibitions and field excursions, contributions from foreign correspondents, as well as book reviews keep both professional and amateur geologists abreast of developments and advances in the field.

\section{Subscription Information}

Geology Today is published bi-monthly. Subscription rates for 1989 are, for individuals $£ 17.50$ (UK), $£ 20.50$ (overseas), $\$ 36.50$ (USA \& Canada), and for institutions $£ 52.50$ (UK), $£ 63.00$ (overseas), $\$ 105.50$ (USA \& Canada) post free. Members of The Geological Society and The Geologists' Association are entitled to subscribe at special rates; details are available from the Society and the Association.

\section{Order Form}

Please tick the appropriate box and return to Blackwell Scientific Publications Ltd, P.0. Box 88, Oxford, England.

$\square$ I would like to subscribe to Geology Today

$\square$ I wish to pay by cheque/money order (delete as necessary) and enclose the sum of

$\square$ I wish to pay by Access/Barclaycard/VISA/Mastercard (delete as necessary)

Please debit my credit card no.

Expiry date

with the sum of

Signature

Date

Please send me a specimen copy of Geology Today

Name

Address.

\section{Blackwell Scientific Publications}

P.O. Box 88, Oxford, England 


\section{Journal of \\ Metamorphic Geology}

\section{Editors}

Dr Michael Brown

Kingston Polytechnic, $U . K$.

\section{Dr D. Robinson}

University of Bristol, U.K.

Professor H.W. Day University of California, U.S.A.

\section{Professor R.H. Vernon Macquarie University, Australia}

Launched in 1983, this journa! brings together research on all aspects of metamorphic geology from a wide range of specialties and is designed to appeal to workers in the fields of metamorphic petrology, mineral deposits geology, geochemistry and other related fields in geology.

The scope of the journal extends over the whole range of metamorphic studies from the scale of the individual crystal to that of the lithospheric plate, including the properties of metamorphic minerals, the theoretical and experimental study of metamorphic reactions, the geochemistry of metamorphic rocks (including isotope geochemistry and fluid inclusion studies), microstructural studies of metamorphic rocks, deformation in relation to metamorphism, regional studies of metamorphic terrains (including geochemistry and geophysics), the environment of formation of metamorphic rocks, and economic aspects of metamorphic terrains (including the metamorphism of mineral deposits).

\section{Subscription Information}

Journal of Metamorphic Geology is published bi-monthly. Subscription rates for 1989 are $£ 97.00$ (UK), $\$ 195.00$ (USA \& Canada), $£ 116.50$ (elsewhere) post free.

\section{Order Form}

Please tick the appropriate box and return to Blackwell Scientific Publications Ltd, P.O. Box 88, Oxford, England.

I would like to subscribe to Journal of Metamorphic Geology

I wish to pay by cheque/money order (delete as necessary) and enclose the sum of

I wish to pay by Access/Barclaycard/VISA/Mastercard (delere as necessary)

Please debit my credit card no.

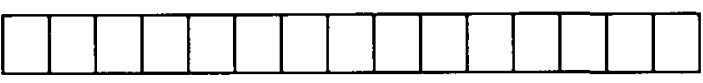

Expiry date. with the sum of

Signature Date

Please send me a specimen copy of Journal of Metamorphic Geology

Name

Address 
Original artwork should be submitted at $1 \frac{1}{2} \times$ size to be published. The Author's name and figure number should be clearly marked on the back of each piece of artwork. Figures will preferably be either single or double column width when printed (see Figure 1). Illustrations should have scale bars, not ' $\times 40$ '. If redrafting is required by the editors, it may be because major savings in print area can be achieved without loss of information: a figure at column width and at half a column height is equivalent to 300 words; the same shaped diagram printed to double column would take a whole page -1200 words. Detailed maps or multiple logs may well require a whole page and the

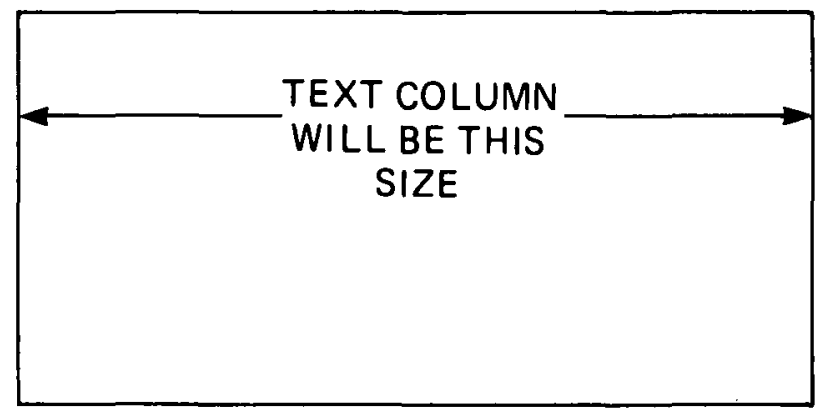

size of the lettering should match the necessary reduction. Where necessary break a figure into two facing pages; folding figures will not be accepted. Landscape figures should have no lettering upside down on the final printed page. Avoid where possible gross disparities in lettering size on a drawing. See Figure 2 for optimum size of original and final lettering size. Boxes of ornament should be explained within the figure, not in the caption. The Magazine will be able to publish a limited number of free colour plates each year; the editors will decide which plates to accept on their scientific merit. Authors submitting colour plates are asked to give detailed reasons why colour is necessary.

\section{HEIGHT OF FIGURE CAN VARY IN EITHER CASE UP TO FULL PRINT AREA HEIGHT $=240 \mathrm{~mm}$}

Figure 1

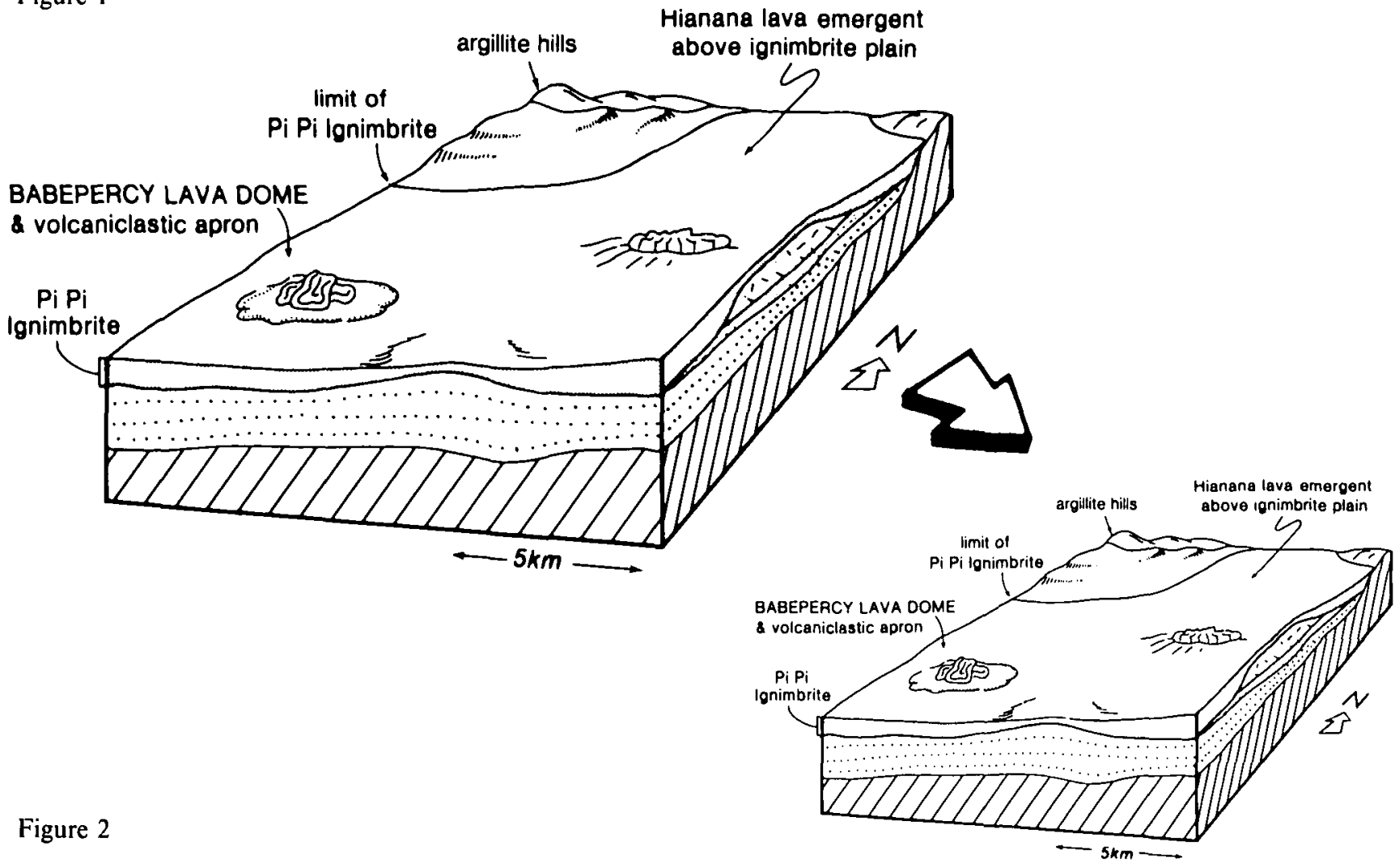


Contributions for publication should be addressed to The Editors. Geological Magazine. Department of Earth Sciences. Downing Street. Cambridge CB2 3EQ. England, or may be submitted through a member of the Editorial Advisory Board (addresses inside front cover). Submission implies that the manuscript has not been published previously nor currently submitted for publication elsewhere.

All contributions. whether articles, correspondence or reviews, must be sent in triplicate and typed on one side of the paper. with wide margins and double-line spacing throughout. Any minor corrections should be made neatly in the typescript, leaving the margins clear. Contributions should follow the general style of papers in recent issues of the Magazine. The total length of a paper should not in general exceed 12 pages of the new A4 format of the Magazine, or 13000 word-equivalents. Priority may be given to short papers. The author is invited to nominate up to five possible referees, who will not necessarily be used.

Articles must be accompanied by a brief, informative rather than indicative, abstract. Headings should be set out clearly but not underlined. Primary headings should be in lower case, at margin, with arabic numeral; subheadings should be numbered 2.a., 2.b.. etc., and tertiary headings 2.a.I., 2.a.2. No crossreferences should be given by page number, but 'above' and 'below' should be used with the section specified, e.g. Section 2.a.2. The SI system of units should be used. The author should mark in the margin of the manuscript where figures and tables may be inserted. References to points in larger works should. where possible, quote the page reference, e.g. Ager. 1981. p. 102.

Tables should be typed with double-line spacing on sheets separate from the running text. Each table must have a caption that will make the data in the table intelligible without reference to the text.

Illustrations should be prepared following the notes for guidance on the facing page. Duplicates of illustrations should be sent, and may be prints or. preferably, photocopies reduced to final size. Figures composed of photographs should be glossy prints presented at publication scale. Figure captions must be typed with double-line spacing on sheets separate from the running text.

The accuracy of references is the responsibility of authors. References must be double-spaced and spelt out in full. e.g.

Brooks, M. \& James, D. G. 1975. The geological results of seismic refraction surveys in the Bristol Channel, 1970-73. Journal of the Geological Society of London 131, 163-82.

Books should be cited as:

Ager. D. V. 1981. The Nature of the Stratigraphical Record. 2nd ed. London: Macmillan, $122 \mathrm{pp}$.

Bott, M. H. P. 1973. The evolution of the Atlantic north of the Faroe Islands. In Implications of Continental Drift to the Earth Sciences, vol. I (eds. D. H. Tarling and S. N. Runcorn), pp. 175-89. London, New York: Academic Press.

Unpublished work should normally be referred to in the text in parentheses as, for example. private communication' or 'unpub. Ph.D. thesis, Univ. London, 1988 , and not included in the reference list unless in the press.

Fifty offprints of each paper will be provided free of charge. Additional offprints may be purchased according to a set scale of charges if ordered when the proofs are returned.

Back Volumes: Vols, 160 and 112 out of print. Vols. 61-111: Enquiries to Wm Dawson \& Sons Ltd. Cannon House, Folkestone, Kent. Volumes 113 onwards are available from Cambridge University Press.

Copring

This journal is registered with the Copyright Clearance Center, 27 Congress St., Salem. Mass. 01970. Organizations in the USA who are also registered with C.C.C. may therefore copy material (beyond the limits permitted by sections 107 and 108 of US copyright law) subject to payment to C.C.C. of the per-copy fee of \$5.00. This consent does not extend to multiple copy for promotional or commercial purposes, Code 0016-7568/ $89 \$ 5.00+.00$.

For all other use, permission should be sought from Cambridge or the American Branch of Cambridge University Press.

Claims for missing issues can only be considered if made immediately after receipt of the subsequent issue.

Adrertising: Details of advertising in Geological Magazine may be obtained from the publisher. 


\section{Geological Magazine}

\section{Volume 126, Number 2, March 1989}

DRUitT, T. H., MEllors, R. A., PYLE, D. M. \& SPARKS, R. S. J.

Explosive volcanism on Santorini, Greece

GIBB, F, G. F \& HENDERSON, C. M. B.

Discontinuities between picritic and crinanitic units in the Shiant Isles sill: evidence of multiple intrusion

HOFMANN, H. J. \& PATEL, I. M.

Trace fossils from the type 'Etcheminian Series' (Lower Cambrian Ratcliffe Brook Formation). Saint John area. New Brunswick, Canada

DE SILVA, S. L.

The origin and significance of crystal rich inclusions in pumices from two Chilean ignimbrites

McNAMARA, K. J. \& AH YEE, C.

A new genus of brissid echinoid from the Miocene of Australia

ARTHUR, M. J.

The Cenozoic evolution of the Lundy Pull-Apart Basin into the Lundy Rhomb Horst

REVIEWS 